\title{
WORK EXPERIENCE, INTERPERSONAL COMMUNICATION ON PERFORMANCE AND USE OF INFORMATION TECHNOLOGY, AIRCRAFT MAINTENANCE COMPANIES
}

\author{
Wulandari Harjanti \\ dra.wulandariong@gmail.com \\ Tri Wahjoedi \\ Anita Kartika Sari \\ Pompong Budi Setiadi \\ Sekolah Tinggi Ilmu Ekonomi Mahardhika \\ Suhermin \\ Sekolah Tinggi Ilmu Ekonomi Indonesia (STIESIA) Surabaya
}

\begin{abstract}
ABSTRAK
Penelitian ini untuk mengkaji peran pengalaman kerja, Keterampilan Komunikasi Interpersonal terhadap Kinerja dan Penggunaan Teknologi Informasi sebagai Moderasi. Data primer diperoleh dari wawancara kepada 61 responden pada Perusahaan Lini Pemeliharaan Pesawat di Surabaya, Indonesia. Unsur-unsur individu dalam organisasi akan menunjukkan perilaku yang berbeda satu sama lain. Ciriciri orang ini akan terbawa ketika memasuki lingkungan baru, yang diwujudkan dalam susunan suatu hierarki, pekerjaan, tanggung jawab, dan lainnya. Hasil penelitian ini adalah Pengalaman Kerja tidak berpengaruh signifikan terhadap Kinerja. Keterampilan Komunikasi Interpersonal berpengaruh signifikan terhadap Kinerja. Penggunaan Teknologi Informasi berpengaruh signifikan terhadap Kinerja, tetapi Penggunaan Teknologi Informasi hanya berperan sebagai prediktor antara Pengalaman Kerja terhadap Kinerja dan Keternampilan Komunikasi Interpersonal terhadap Kinerja. Belum ada penelitian yang mengkaji model sebagaimana tersebut di atas. Kajian ini memberikan gambaran tentang aspek-aspek yang harus diperhatikan guna menjaga dan meningkatkan kinerja di suatu departemen yang menjunjung tinggi keselamatan penerbangan.
\end{abstract}

Kata kunci: teknologi informasi, komunikasi, pekerjaan, perawatan pesawat kerja.

\section{ABSTRACT}

This research is to examine the role of work experience, Interpersonal Communication Skills on Performance and Use of Information Technology as Moderation. Primary data were obtained from interviews with 61 respondents at an Aircraft Maintenance Line Company in Surabaya, Indonesia. Individual elements in the organization will show different behavior from one another. The characteristics of this person will be carried over when entering a new environment, which is manifested in the arrangement of a hierarchy, work, responsibility, and others. The result of this research is that work experience has no significant effect on performance. Interpersonal Communication Skills have a significant effect on performance. The use of information technology has a significant effect on performance, but the use of information technology only acts as a predictor between work experience on performance and interpersonal communication skills on performance. There is no research that examines the model as mentioned above. This study provides an overview of the aspects that must be considered in order to maintain and improve performance in a department that upholds aviation safety.

Key words: information technology, communication, work, aircraft maintenance. 


\section{INTRODUCTION}

Understanding of Human Re-sources is an integrated ability and interaction between the power of thought (mind) which is added to the knowledge and experience as well as the physical power (skills) possessed by each individual human being. Thinking power is intelligence (basic capital) brought by humans from birth to make humans able to do things that are impossible to do physically or human physical power, where by using their reason humans are able to find ways or solutions to various problems that cannot be solved, able to be carried out by human physical power with various innovations and ideas that are processed by the human mind.

Human intelligence is measured by Intelligence Quotient (IQ) and Emotion Quality (EQ). While physical power in the form of skills or abilities can be through training and learning efforts by humans themselves. In other words, human ability itself is determined by the power of thought and physical power so that humans become the main element in activities both individually and in organi ations. For example: sophisticated equipment or machines with high technology such as laptops, etc., all of which are the result of human thought or reason that aims to ease human physical work.

The role and importance of Human Resources in the organi ation is that all potential human resources that can be utilized as an effort to achieve success in achieving goals both individually and within the organi ation. These resources, namely time, energy and human capabilities (both thinking power and physical power) can really be utilized in an integrated and optimal manner for the benefit of the organi ation. Human Resources as the first and main factor in the development process and the achievement of organi ational goals. If the organi ation already has large capital, advanced technology, abundant natural resources but there are no human resources that can manage and utili e it, it will not be possible to achieve success in achieving organi ational goals.

Therefore, the importance of the role of human resources in the organi ation is very necessary as the main element and element controlling the success of the organi ation. Safety is the most important thing in this service business where the level of flight safety performance can be seen from the number of flight accidents that occurred, the types of accidents that occurred, and the number of passengers/crew who survived the accident. Meanwhile, service performance can be seen from customer satisfaction after using this service. Timeliness performance is a performance that is measured based on the airline's ability to provide flight services on time or in other words the airline's ability to carry out flight activities according to the scheduled time. This scheduling refers to three types of decisions, namely aircraft maintenance, list of departure hours, and flight crew (Heizer and Render, 2011). Aircraft maintenance includes all activities related to maintenance and ensuring system equipment can work properly (Daulay et al., 2013). Strategies in maintenance, for example implementing and improving preventive maintenance activities as well as increasing skills and speed of repairs (Daulay et al., 2013). This activity is very important to do in order to prevent engine failure, especially in maintaining the safety of passengers and crew when flight activities are carried out.

To achieve fast and precise performance, especially productivity, the human factor with work experience is a very important variable, as it is influenced by the accuracy and speed of decisions made by technicians when carrying out aircraft repairs in the maintenance line. In addition, communication is also believed to be able to improve the quality of the resulting performance.

In this case, the communication carried out by an employee allows the creation of an empathetic attitude to create a comfortable and harmonious atmosphere, and is able to carry out an attitude of openness to the work 
he does. In addition to work experience and interpersonal communication skills, the application of information systems and the use of information technology are also important variables because the aircraft maintenance industry is one of the industries with the highest level of dependence on the collection, analysis and submission of reports (information) needed to fulfill maintenance activities.

Interpersonal communication skills are the ability to communicate effectively with others. Interpersonal communication skills contain knowledge of the rules in non-verbal communication such as touch, physical proximity, knowledge of how to interact according to context, paying attention to people communicating and paying attention to the volume of the voice. These rules contain ethics. Ethics is an element that must be considered in interpersonal communication skills (Okoro et al., 2017). Interpersonal communication skills are required in all types of interpersonal communication, both direct and indirect communication.

Indirect interpersonal communication is communication that occurs through media, such as letters, telephone or online. Indirect interpersonal communication with online media is the most widely used option today. The majority of online communication users are the younger generation. According to Valkenburg and Peter (2011) online communication is attractive to youth due to several factors, namely; Compared to faceto-face communication, online communication increases control of self-presentation and self-disclosure, individuals will feel more secure, freer in establishing interpersonal interactions than interacting directly with face to face. In everyday life, humans cannot be separated from the influence of other humans. Humans are social creatures who influence the behavior of others and are influenced by their behavior. Social relationships depend on mutual adjustments between these behaviors.

In socializing, interpersonal communication skills are needed, interpersonal com- munication is most often considered a set of skills that allow us to communicate, relate and sociali e with other people. The phenolmenon of the low level of interpersonal communication skills in schools can be seen based on the behavior seen in students, including: students who are shy in expressing opinions, have poor communication behavior with other students, causing disputes and fights, and students who feel less confident in establish relationships with their peers.

Effective interpersonal communi-cation skills are essential for building and maintaining relationships in social interactions. Poor communication skills can cause relationship damage, affecting productivity, satisfaction, performance, morale, trust, respect, self-confidence, and even physical health.

Behavior, performance, and work results are not the same. Work behavior is everything that an individual does at work. Work performance is the expected organi ational value of individual work behavior. Work results are circumstances or conditions of individuals or objects that change because of what they do to contribute to or deviate from organi ational effectiveness. Therefore, results are a way for individual behavior to help or hinder the organi ation from achieving its goals, this is what causes us to tend to focus on work results when thinking about individual work performance.

There are at least two conceptual and practical benefits when we construct work performance constructs from individual behavior rather than from individual behavioral outcomes. First, the circumstances and conditions of objects or individuals that change due to individual behavior are also often influenced by other factors that are beyond the control of the individual himself.

This argument considers the difference between two types of situations, obstacles or opportunities. One type of situation will affect the likelihood of whether the individual will perform the behavior that is expected to help or hurt the organi ation. It is 
these two types of situations that determine work performance as previously stated.

Situational factors of this type make whether a person finds it easy or difficult to display behaviors that potentially contribute to or hinder organi ational effectiveness by directly opposing or facilitating the emergence of behavioral responses that oppose organi ational effectiveness. For example, the availability of required equipment or scarce resources will affect the likelihood of an individual to display behaviors that involve the use of such equipment and raw materials to produce products or services for the organi ation; Meanwhile, the second type of situation of obstacles and opportunities will affect the expected work results of the organi ation without having to affect the behavior of individual work performance. For example, economic factors and market conditions can have a direct impact on sales volume and profits without having to hinder or facilitate the work performance behavior of individuals involved in the process of producing goods or services.

So, although the situation of obstacles or opportunities that affect individual behavior is seen as a determinant of work performance, the situation of opportunities or obstacles that impact on the results of individual behavior is not seen as a determinant of work performance.

This study aims to examine the effect of work experience and interpersonal communication skills on work performance and the use of information technology as a moderator. What is new here is the modeling between these 4 variables to look for factors that influence performance in line maintenance aircraft maintenance companies in Surabaya, Indonesia, where the results of this study can be used for similar companies for improvement and new discourses in organi ational behavior research. Effective interpersonal communication can be achieved with good interpersonal communication skills.

This paper is structured as follows: Section 2 provides a literature review of this paper. Section 3 discusses the methodology. Section 4 describes data collection, data processing and analysis of findings and discussion. Section 5 concludes the research results.

\section{LITERATURE REVIEW}

Opinion Hasibuan (in Nasir et al. 2020), the continuity of the company's operations depends on the performance of the people in the company. Performance is the work done by a person in carrying out the tasks assigned to him based on ability, experience and seriousness and time. A person's performance is a combination of abilities, effort and opportunities obtained from the results of his work. The factors that affect employee performance are knowledge, attitudes, abilities, experience and reputation perceptions (Sutrisno, 2011: 111).

Work experience is a knowledge, skills and abilities that employees have in carrying out the responsibilities of their previous jobs (Susanti and Wariati, 2015). Experienced people are prospective employees who are ready to use (Hasibuan, 2016: 55). Work experience can be seen from: the length of time / years of work, the level of knowledge and skills possessed and the mastery of work and equipment.

Work experience is a level of proficiency Employee knowledge and skills Work that can be measured from the time of Job and the type of work done by the employee We do it within a certain period of time. Work experience is based on employees Knowledge and skills. It is consistent with Robins and Timothy's Theory (in Usman et al., 2021).

In the activities of using human resources, it is known that humans are potential resources in determining the success of the company, therefore it must be considered so that the smooth running of the company is increasing.

The quality of human resources can be seen from the results of their work, within the framework of professionalism, good performance is as if an employee is able to 
demonstrate work behavior that leads to the achievement of the company's goals and objectives, for example how to manage human resources in order to lead to good work results good, because humans can be the center of problems for companies when their potential is not optimally developed, on the other hand humans can be the center of success for companies when their potential is developed properly and optimally.

Internally, in the management and improvement of the company's management, human resources occupy a strategic position. Even though it is supported by large capital and reliable technology without being supported by human resources capable of running it, the company's goals will not be achieved. The purpose of establishing a company is to obtain optimal profits in accordance with the plans that have been made. In the development of the company is expected to progress, bright hope in the future is one of the basis for taking actions that are considered necessary at this time.

However, in this case the company maintains and develops a company that has been established, which is a much more difficult application because it will involve a variety of problems that are more numerous and alternate. So even if a company has modern equipment with high technology, humans are still the driving force, in this case the workforce or employees, without human resources and work experience the company's employees will not function properly.

Learn human resource management as a necessary knowledge to have the ability to analy e in dealing with management problems, especially in the field of organi ation. The existence of an effort to use work experience will produce quality human resources, in this case the performance of the employee concerned and able to give the best contribution in achieving company goals. Human resources or the performance of its employees. Therefore, the role of human resources in the company is very important because it is the main driver of all company activities. The success or failure of a company in maintaining the existence of the company starts from the human effort itself in increasing work effectiveness and efficiency to the maximum.

This achievement also needs to be linked to the behavior of employees during the performance development process. Performance management is often referred to as part of human resource management which has the greatest effect on organi ational performance. It is further stated that the purpose of performance management is to link or link individual targets and responsibilities with targets and response-bilities of work units and the organi ation as a whole.

The rapid development of information systems and information technology is a competitive weapon that companies must have. The application of information systems and information technology is said to be successful if it can improve performance (Lindawati and Salamah, 2012). Information and communication technology (ICT) as a medium or aids in gaining knowledge between one person and another (Rusman et al., 2012: 88).

Information Systems and Information Technology as Strategic Means Identify Opportunities. Explained and illustrated by the selected example by F. W. McFarlan (Sevrani, 2011). Strategic application of Is / It in the organization the four main types of strategic systems seem to be: 1 . Someone who has information about technologybased systems. share Change types with customers / consumers and / or suppliers' relationship; 2 . Those who want a more effective integration of their use Information in the organization's value creation process. 3. Organization develops, produces, sells, and informedly provide new or improved products or services. 4 . Persons who provide information to senior management Strategy development and implementation support (Especially when relevant external and internal information is available Integrated into analysis).

In addition, communication is also able to improve the quality of the resulting 
performance. Communication skills are also an exchange, namely the act of conveying and receiving messages as reciprocity with the understanding of all communicating parties about the messages used in the communication process (Daryanto and Rahardjo, 2016). Interpersonal communication is the process of sending and receiving messages between two people or a small group of people, with some effects and some instantaneous feedback (Laksana, 2015). Work experience affects work motivation, then it affects work performance (Wulandari, 2017).

To improve performance, many companies rely on people or employees who have work experience. With this experience, it is expected to improve performance. Work experience affects performance (Pratiwi et al., 2019). Work experience fosters satisfaction, which in turn affects performance (Muntazeri and Indriyanto, 2018). Work experience together with independence and professional skills have a significant effect on performance (Astika and Wirasedana, 2020).

In addition, partially and or simultaneously interpersonal communication and work motivation have a significant positive effect on employee performance. Department performance can be improved through developing employee interpersonal communication capacity and strengthening work motivation (Abdurrahman, 2018). Being an employee will usually feel bored and want to replace the position of the owner of the company. With such an attitude, employees must begin to be noticed by superiors by developing motivation, and so that the motivation that has been built can grow again, it must be known how to provide good motivation.

The use of information technology has a positive and significant effect on employee performance. Meanwhile, the variables of interpersonal communication skills and leadership style have no significant effect on employee performance (Zakaria and Leiwakabessy, 2020). Interpersonal communication has a positive direct effect on performance. Leadership has a direct and positive effect on Interpersonal Communication (Fanpada, 2020). Communication is an inseparable part of all human activities. Communication greatly affects the work motivation of members, where motivation is the driving force that underlies the enthusiasm to do something. Work motivation is a spirit that is expected by every individual to work hard to achieve maximum results. The existence of interpersonal communication is expected to be an alternative to increase the work motivation of members. Here it states that communication is not only the job of a manager, because motivation can come from oneself or other members who play an active role in the organi ation

Opinions Kadir and Triwahyuni (2013: 4) classifying information technology into two parts: "Information technology can be divided into two parts, the device software and device hardware. Device hardware including physical equipment, such as memory, Printer and keyboard devices is software include: instructions for setting up hardware in order to operate in accordance with the instruction of interest. In addition to the Kadir and Triwahyuni (2013: 11) divide information systems into elements or basic functions that interact with each other, namely: Input, Processing, Output, Storage, Control.

Based on the elements of information technology, it can be described as follows:

1). Input devices are equipment that can be used to receive data that is processed in a computer. A device is a device that a user uses to interact with a computer so that the computer executes the commands given by the user. The working principle of the device performed on the input is a command that can be understood by humans to change the form that is understood by the computer, meaning changing the sequence into a form that can be understood by humans. On data for which the computer understands that the code is binary. Input devices can be 
classified into two categories, namely the input device directly and input devices indirectly. Input devices are directly whereas inputs used directly processed by the CPU, without the use of other media. While the input device does not directly process the input that is not entered by the CPU.

2). Involves a transformation process that converts inputs into outputs. CPU is the main processing component of the information system. Processing activities include receiving input from the data that perform mathematical calculations and maintain data files

3). Involves moving the elements produced by the transformation process to their final destination. And this is the lat output of the computer system converting information generated electronically by computer systems in a form that can be presented to users so that it can assist in decision making, evaluation and control of the organi ation. The goal is to produce accurate, accurate, accessible and complete information.

4). The information system storage function resides in a series of primary storage unit storage (memory) supported by secondary storage (such as magnetic floppy and optical disks). To store data and instructions, the instrument has the necessary software for processing. Storage devices can eat data when the computer is turned off.

5). Control will involve monitoring and evaluating the feed to determine whether the system is approaching the target or not. The function control will then make the necessary adjustments or the component input processing system. So that the system produces the appropriate output. Feedback is data to determine system performance that contains feedback and control components, commonly called cybernetic systems, namely systems that monitor and regulate their own systems.
Each task and processing information that can be used by individuals, or can also be combined to obtain an information system that can handle all tasks. The ability of information technology in influencing events in the business world is something that cannot be processed anymore, even though in terms of technology it is still more sophisticated and sophisticated. The presence of technology is a source of strength that provides a competitive advantage for companies and is defined as a factor that provides retaliation for business success.

The sophistication of technology in the past has now grown rapidly and is even capable of producing various kinds of technological systems designed to support human work to produce information of the best quality. Technological diversity that provides ease of implementation to technology users. Companies that have information technology that has been enhanced (automatic and integrated) and supported by the application of modern supporting technology, are expected to have a positive influence on the continuity of the company's performance in order to produce financial reports in a timely, accurate, and reliable manner. The definitions of information technology purification are as follows:

The definition of information technology purification according to Raymond and Pare (in Granell et al. 2014: 57) is: "Implementation of information technology is defined as a multidimensional construct space that refers to the nature, interdependence, complexity and use of information technology and management in an organization. Therefore, the concept of integrated information filtering both aspects related to the use of information systems and information management systems

From the above definition, it is conveyed that the improvement of information techno$\log y$ in a multidimensional manner refers to the nature, complexity and interdependence of the use of information technology and management in an organi ation. Therefore, the concept of improving information 
technology integrates two aspects related to the use of information systems and management information systems.

According to Huber (in Al Eqab and Adel, 2013), the sophistication of information technology is: "The use of sophisticated IT causes the retrieval of more available and faster information, including external information, internal information and previously discovered information, thus leading to more information information ".

From the definition above, it can be concluded that the usefulness of IT improvements results in information that is more available and faster to obtain, including external information, internal information and information that has existed previously so as to increase the accessibility/affordability of information. According to El Loudi (in Al Eqab and Adel, 2013), the sophistication of information technology is: "That the sophistication of the IT organi ation directly affects the amount of external and internal information provided".

From the above definition it can be concluded that the sophistication of IT in the organi ation has a direct effect on the amount of information contained in external and internal media. According to Raymond and Pare (in Cragg et al., 2010) defines that the sophistication of information technology is: "Sophisticated technology here is defined as a construct that refers to the nature, complexity and interdependence of the use and management of IT in an organi ation". Of all theories of improvement of information technology is a construct that refers to the use of the nature, complexity and interdependence between information and technology management that is able to produce various kinds of technology systems designned to support human work to assist in the production of quality information. Companies that have advanced technology (automatic and integrated) supported by applications that support modern technology are expected to have a positive impact on the survival of the company in a timely, accurate and reliable manner.
According to Ismail and King (in Al Eqab and Adel, 2013), there are four dimensions of information technology sophistication, namely: 1) technological sophistication, 2) information sophistication, 3) functional refinement and 4) technological sophistication. Management refinement to measure the impact of information technology on the smoothing of accounting information features. The dimensions of technological sophistication according to Granell et al. (2014: 57) are: "Technological sophistication refers to the amount and variety of information technology used, as well as the nature of the hardware and development tools used by the company. From the above definition it can be concluded that technological sophistication refers to the amount and diversity of information technology used as well as the nature of the hardware and tools developed by the company.

The dimensions of information improvement according to Granell et al. (2014: 57) are: "Information improvement refers to the nature of the application portfolio, both transactional and administrative applications. Another aspect of information sophistication, identified by Ein-Dor and Segev, relates to the level of application integration, which is primarily characterized by the presence of software (e.g. Database) or hardware (e.g. Local network) exchanging and sharing resources. From the above definition, it can be concluded that information improvement refers to the nature of the application portfolio, both transactional and administrative applications. In addition to the data refinement provided by the EinDor and Segev aspects, related to the level of application integra tion, mainly characterized by the presence of software (e.g. databases) or p-devices, hardware (e.g., local area networks) that allow information exchange and sharing resource.

Dimensions of functional improvement according to Granell et al. (2014: 57) are: "Functional improvement relates to the structural aspects of the information system 
function (eg the location and autonomy of the IS function and the number of internal information system specialists) and information technology.

Implementation process (eg method, source and application uniqueness) from the above definition it can be concluded that the improvement of function is related to the function of information system which is a structural aspect (eg location and function of autonomous information system and number of special information systems internally) and implementation of information technology (e.g. method, source, and application uniqueness).

\section{RESEARCH METHOD}

This study uses a quantitative type of research, because the researcher wants to confirm the concepts and theories that have been described in the previous chapter with the facts and data found in the field. And data collection:

1. Primary Data, according to Sugiyono (2017: 193) the primary source is the retrieval of data obtained directly by researchers from the field. This source can be obtained by researchers through: a). Questionnaire, data was collected using a questionnaire or questionnaire method, namely by giving questions directly through a questionnaire to the respondents. Questionnaires are used to obtain data about the dimensions of the constructs being developed in this research. Statements in the questionnaire are made using a scale of 0 to 10 to obtain interval data and are given a score or value. The list of questions does not contain a detailed statement of the respondent's identity. This is done with two arguments. First, the identity of the respondent is not very meaningful in answering the research hypothesis. Second, this is to increase the objectivity of respondents' answers, because respondents are free to give answers according to their experiences without any desire to hide anything. b). Interview is a method or method of collecting data and various information by asking directly to someone who is considered an expert in their field and also authorized to solve a problem.

2. Secondary Data is data obtained indirectly or archive research containing past events. This secondary data can be obtained by researchers from journals, magazines, books, statistical data and the internet. When a researcher uses data obtained from the central statistical agency, it can be said that the researcher is using secondary data.

Population according to Sugiyono (2017: $117)$, is a generali ation area consisting of objects or subjects that have certain qualities and characteristics determined by the researcher to be studied and then draw conclusions. In this study, the population used was all employees of aircraft maintenance companies in Surabaya who were selected only from line maintenance, as many as 61 people.

According to Arikunto (2012: 104), if the population is less than 100 people, the total sample is taken, but if the population is greater than 100 people, $10-15 \%$ or $20-25 \%$ of the population can be taken. Based on this research, because the population is not more than 100 people. For this reason, the sample of respondents taken in this study were all employees totaling 61 people.

According to (Noor, 2011: 138) data collection techniques are a way of collecting data needed to answer problem formulations (research). This study uses a data collection technique, namely a questionnaire. The questionnaire is a data collection technique by providing or distributing a list of questions to respondents in the hope that they can respond to the list of questions. In this case, the respondents are employees with a total of over 61 people.

The operational understanding of a variable is an element of research that tells how to measure a variable or it can be said to be a kind of implementation guide on how to 
measure a variable. This study consists of 4 variables to be studied:

\section{WE as Work Experience}

According to Marwansyah (in Wariati et al. 2015) work experience is a knowledge, skills and abilities that employees have to carry out the responsibilities of their previous jobs. Indicators from work experience, namely the length of the work period, the level of knowledge and skills possessed, and competent for the job which is described in the 7 questions.

2. ICS as Interpersonal Communication Skills

According to Laksana (2015), interpersonal communication is the process of sending and receiving messages between two people or a small group of people, with some effects and some immediate feedback. This variable is measured through indicators: desire (expec- tation), service, and behavior which is described in the 5 questions.

3. WP as Work performance

According to Rosman (2014), indicators for measuring individual work peformance are quality, quantity, timeliness, effectiveness, independence, and work commitment which is described in the 6 questions.

4. IT as Use of information technology According to Lindawati and Salamah (2012), the rapid development of information systems and use of information technology makes it a competitive weapon that a company must have in winning the competition. The application of information systems and use of information technology can be said to be successful if it can improve work performance, which in turn can improve company performance. The measurement is based on indicators of intensity of use and frequency of use which is described in the 4 questions.

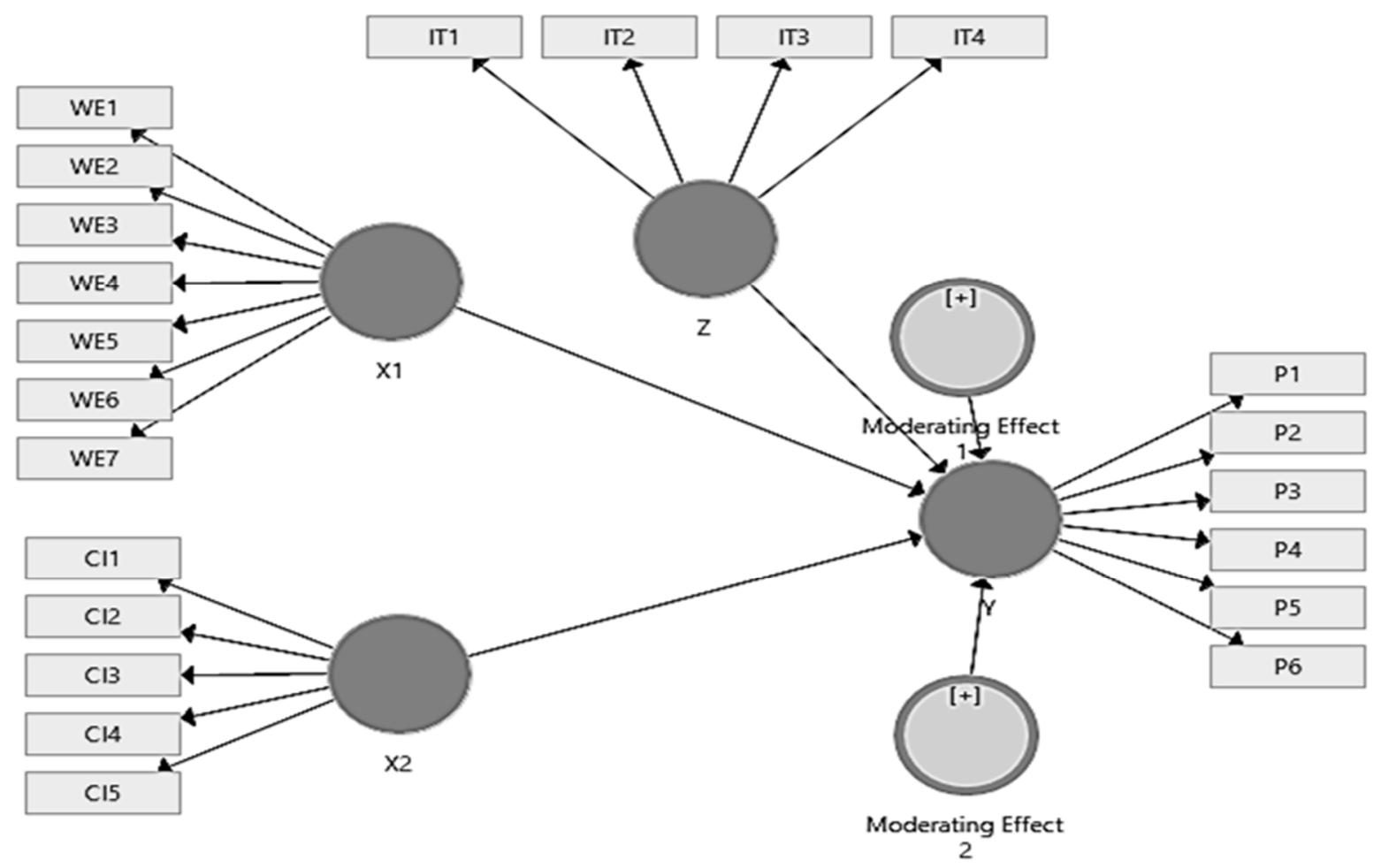

Figure 1

Source: data in the researchers

\section{Structural Model}


In this study, the collected data were analyzed using Partial Least Square (PLS), Partial least square is a multivariate statistical technique that can handle many response variables as well as explanatory variables at once. This analysis is a good alternative to the multiple regression analysis method and principal component regression, because this method is more robust or immune. Robust means that the model parameters do not change much when a new sample is taken from the total population. Partial Least Square is a predictive technique that can handle many independent variables, even if there is multicollinearity between these variables, and structural equation modeling using the Smart PLS 3 program with structural model as figure 1 .
Hypothesis:

- H1-There is a direct significant effect of Work Experience on Work performance

- H2-There is a direct significant effect of Interpersonal Communication Skills on Work performance

- H3-There is a direct significant effect of Use of Information Technology on Work performance

- H4-There is moderation effect by Use of Information Technology on Work Experience and Work performance

- H5-There is moderation effect by Use of Information Technology on Interpersonal Communication Skills and Work performance

Table 1

Result for Outer Loading

\begin{tabular}{|c|c|c|c|c|c|c|}
\hline & M.E 1 & M. E.2 & X1 & $\mathrm{X2}$ & $\bar{Y}$ & $\bar{Z}$ \\
\hline C11 & & & & 0,928 & & \\
\hline $\mathrm{C} 12$ & & & & 0,951 & & \\
\hline $\mathrm{C} 13$ & & & & 0,748 & & \\
\hline C14 & & & & 0,779 & & \\
\hline C15 & & & & 0,923 & & \\
\hline It1 & & & & & & 0,892 \\
\hline It2 & & & & & & 0,861 \\
\hline It3 & & & & & & 0,916 \\
\hline It 4 & & & & & & 0,841 \\
\hline P1 & & & & & 0,899 & \\
\hline P2 & & & & & 0,799 & \\
\hline P3 & & & & & 0,876 & \\
\hline P4 & & & & & 0,859 & \\
\hline P5 & & & & & 0,902 & \\
\hline P6 & & & & & 0,875 & \\
\hline WE1 & & & 0,889 & & & \\
\hline WE2 & & & 0,631 & & & \\
\hline WE3 & & & 0,930 & & & \\
\hline WE4 & & & 0,941 & & & \\
\hline WE5 & & & 0,910 & & & \\
\hline WE6 & & & 0,776 & & & \\
\hline WE7 & & & 0,783 & & & \\
\hline$X 1^{*} \mathrm{Z}$ & 2,124 & & & & & \\
\hline $\mathrm{X} 2 * \mathrm{Z}$ & & 2,096 & & & & \\
\hline
\end{tabular}

Source: processed data 


\section{ANALISYS AND DISCUSSION ANALYSIS}

A. Evaluation of Measurement (Outer Model)

1. Validity test

An indicator can be declared valid if the indicator has a loading factor above 0.5 on the intended variable. The Smart PLS 3 output for the loading factor provides the following analysis results (table 1).

The validity test of the reflective Source:

Indicators uses the correlation between item scores and variable scores. In correlation, which is one of the many analytical techniques in statistics, it is used to find the relationship between two quantitative variables. The relationship between the two variables can occur because of a causal relationship or it can also occur by chance. Two variables are said to be correlated if changes in one variable will be followed by changes in the other variables regularly in the same direction (positive correlation) or opposite (negative correlation).
Measurements with reflective indicators indicate a change in an indicator in a variable if other indicators of the same variable change (or are removed from the model). The table above shows that the loading factor provides a value above the recommended value of 0.5 . The smallest value is 0.631 for the WE2 indicator. This means that the indicators used in this study can be declared valid or have met convergent validity. The following is a diagram of the loading factor for each indicator in this research model (figure 2).

Reflective indicators also need to be tested for their discriminatory validity by cross loading as follows in table 2.

An indicator is declared valid if it has the highest loading factor for the targeted variable compared to the loading factor for other variables. The table above shows that the loading factor for the indicator (WE1 to WE7) has a higher loading factor for the variable than the other variables.

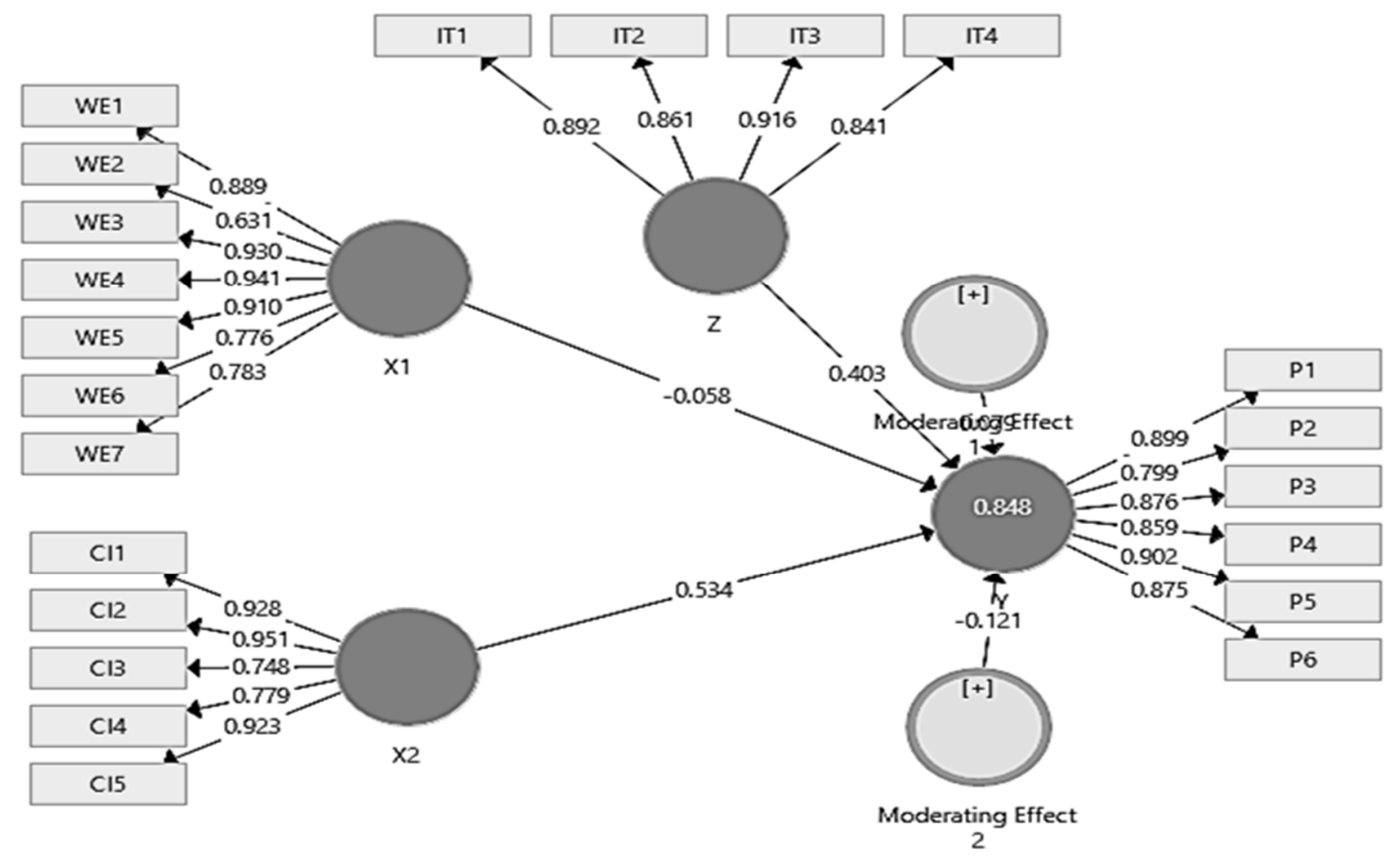

Figure 2

Source: processed data pls

Value of Loading Factor 
Table 2

Result for Cross Loadin

\begin{tabular}{ccccccc}
\hline \hline C11 & ME! & ME2 & X1 & X2 & Y & Z \\
\hline C12 & $-0,618$ & $-0,661$ & 0,739 & 0,928 & 0,840 & 0,790 \\
C13 & $-0,447$ & $-0,634$ & 0,744 & 0,951 & 0,861 & 0,796 \\
C14 & $-0,380$ & $-0,429$ & 0,596 & 0,748 & 0,564 & 0,574 \\
C15 & $-0,572$ & $-0,602$ & 0,673 & 0,779 & 0,672 & 0,660 \\
It1 & $-0,691$ & $-0,693$ & 0,679 & 0,923 & 0,862 & 0,787 \\
It2 & $-0,558$ & $-0,567$ & 0,670 & 0,723 & 0,747 & 0,892 \\
It3 & $-0,607$ & $-0,656$ & 0,664 & 0,793 & 0,722 & 0,861 \\
It4 & $-0,601$ & $-0,598$ & 0,734 & 0,735 & 0,810 & 0,916 \\
P1 & $-0,521$ & $-0,565$ & 0,664 & 0,795 & 0,899 & 0,841 \\
P2 & $-0,490$ & $-0,487$ & 0,704 & 0,714 & 0,799 & 0,741 \\
P3 & $-0,497$ & $-0,531$ & 0,630 & 0,757 & 0,876 & 0,739 \\
P4 & $-0,653$ & $-0,675$ & 0,649 & 0,797 & 0,859 & 0,766 \\
P5 & $-0,491$ & $-0,558$ & 0,569 & 0,778 & 0,902 & 0,718 \\
P6 & $-0,691$ & $-0,767$ & 0,626 & 0,774 & 0,875 & 0,810 \\
WE1 & $-0,654$ & $-0,649$ & 0,889 & 0,722 & 0,629 & 0,711 \\
WE2 & $-0,404$ & $-0,375$ & 0,631 & 0,458 & 0,435 & 0,460 \\
WE3 & $-0,630$ & $-0,609$ & 0,930 & 0,749 & 0,660 & 0,716 \\
WE4 & $-0,625$ & $-0,604$ & 0,941 & 0,782 & 0,707 & 0,755 \\
WE5 & $-0,574$ & $-0,550$ & 0,910 & 0,778 & 0,649 & 0,722 \\
WE6 & $-0,405$ & $-0,392$ & 0,776 & 0,576 & 0,592 & 0,601 \\
WE7 & $-0,416$ & $-0,404$ & 0,783 & 0,634 & 0,637 & 0,604 \\
X1*Z & 1,000 & 0,956 & $-0,634$ & $-0,634$ & $-0,644$ & 0,700 \\
X2*Z & 0,956 & 1000 & $-0,614$ & $-0,614$ & $-0,690$ & 0,717 \\
\hline
\end{tabular}

Source: processed data

As an illustration, the loading factor from WE1 to is 0.889 , greater than the loading factor for X2 (0.772), Y (0.629) and (0.711). The same is seen in other indicators. The big question about this loading factor is, why can an indicator have a high loading factor and another indicator can have a low one? In the relationship between indicators and latent constructs that are reflexive, the high and low loading factors in addition to the correlation coefficient are the variations in the data contained in the indicators. In indicators with low data variation, it is more difficult to measure a latent construct. In other words, differences in latent construct scores are more difficult to explain by indicators with almost the same value (low data variation).
Thus, latent contracts predict indicators in their block better than indicators on other blocks. Another method to see discriminant validity is to look at the square root of the average variance extracted (AVE) value. Recommended value is above 0.5. The following is the AVE value in this study:

Table 3.

Average Variance Extracted (AVE)

\begin{tabular}{cl}
\hline \hline Moderating Effect (ME) & (AVE) \\
\hline ModeratingEffect 1 & 1,000 \\
ModeratingEffect 2 & 1,000 \\
WE & 0,712 \\
ICS & 0,757 \\
WP & 0,755 \\
IT & 0,771 \\
\hline
\end{tabular}

Source: processed data 
Table 3 provides an AVE value above 0.5 for all variables contained in the research model. The lowest AVE value is 0.712 in variable (Work Experience).

\section{Reliability Test}

The reliability test is done by looking at the composite reliability value of the indicator block that measures the variable. The results of the composite reliability will show a satisfactory value if it is above 0.7 (Table 4). Here are the composite reliability values:

Table 4

Composite Reliability

\begin{tabular}{cc}
\hline \hline & $\begin{array}{c}\text { Composite } \\
\text { Reliability }\end{array}$ \\
\hline Moderating Effect 1 & 1,000 \\
Moderating Effect 2 & 1,000 \\
WE & 0,944 \\
ICS & 0,939 \\
WP & 0,949 \\
IT & 0,931 \\
\hline
\end{tabular}

Source: processed data

Reliability test to measure the internal consistency of the measuring instrument. Reliability shows the accuracy, consistency, and accuracy of a measuring instrument in making measurements. The reliability test in PLS can use two methods, namely Cronbach's alpha and composite reliability. Cronbach's alpha measures the lower limit of the reliability value of a construct, while composite reliability measures the reliability value of a construct.

However, composite reliability is considered better in estimating the internal consistency of a construct. The rule of thumb used for Composite Reliability values is greater than 0.7 and Cronbach's alpha value is greater than 0.7 . The table above shows that the composite reliability value for all variables is above 0.7 which indicates that all variables in the estimated model meet the criteria for discriminant validity. The lowest composite reliability value is 0.931 in variable (Use of Information Technology).
Reliability testing can also be strengthened with Cronbach's Alpha where the Smart PLS 3 output gives the following results:

Table 5

Cronbach's Alpha

\begin{tabular}{cc}
\hline \hline & $\begin{array}{c}\text { Cronbach's } \\
\text { Alpha }\end{array}$ \\
\hline Moderating Effect 1 & 1,000 \\
Moderating Effect 2 & 1,000 \\
WE & 0,929 \\
ICS & 0,917 \\
WP & 0,935 \\
IT & 0,901 \\
\hline
\end{tabular}

Source: processed data

The recommended values are above 0.6 and the Table 5 shows that the Cronbach's Alpha values for all variables are above 0.6. The lowest value is 0.901 in the variable (Use of Information Technology).

\section{B. Structural Model Testing (Inner Model)}

After the estimated model meets the criteria for the Outer Model, the next step is testing the structural model (Inner model). The following is the R-Square value of the variable:

Table 6

R-Square

\begin{tabular}{ll}
\hline \hline & R Square \\
\hline WP & 0,848 \\
\hline
\end{tabular}

Source: processed data

Table 6 gives a value of 0.848 for the $Y$ variable, which means that, $\mathrm{X} 2$ and are able to explain the $\mathrm{Y}$ variance of $84.8 \%$. Table 7 provides the hypothesis testing is as follows:

1. The relationship between Work Experience on Work performance is not significant with $P$ values $0.780(>0.05)$. Thus, the hypothesis H1 in this study which states that Work Experience have an effect on Work performance is rejected. 
2. The relationship between Interpersonal Communication Skills on Work performance is significant with $P$ values 0.001 $(<0.05)$. The original sample estimate value is positive, which is 0.534 which indicates that the direction of the relationship between Interpersonal Communication Skills on Work performance is positive. Thus, the hypothesis $\mathrm{H} 2$ in this study which states that the Interpersonal Communication Skills has an effect on Work performance is accepted.

3. The relationship between Use of Information Technology on Work performance is significant with P values $0.009(<0.05)$. The original sample estimate value is positive, which is 0.403 which indicates that the direction of the relationship between use of information technology on Work performance is positive. Thus, the hypothesis $\mathrm{H} 3$ in this study which states that Use of information technology has an effect on Work performance is accepted.

4. There is no moderation effect by Use of Information Technology on Work Experience and Work performance caused $\mathrm{P}$ Values 0.641 ( > 0.05).

5. There is no moderation effect by Use of Information Technology on Interpersonal Communication Skills and Work performance caused P Values 0.484 ( > 0.05).

\section{Discussion}

In preparation for the aircraft maintenance industry in Indonesia to face future challenges, it is necessary to master the information and competence with regula- tions and customer requirements. It is highly recommended to pay attention to human factors, namely to recogni e human factors that affect work performance.

From the research that has been done, it was found that there is a significant direct effect of Interpersonal Communication Skills on Work Performance and the Use of Information Technology on Work Performance, while Work Experience has no significant effect on work performance and Use of Information Technology only act as predictors between to Work Performance and Interpersonal Communication Skills to work performance.

Aspects of communication skills, among others; openness, positivity, empathy, support, equality, readiness and confidence. Openness of interpersonal communication includes several aspects, namely the willingness to express oneself with others.

People who interact with the environment, are willing to respond and treat each person honestly the stimuli received and experienced and are responsible for all thoughts and feelings expressed. The openness of interpersonal communication allows the perpetrator to discuss the problems faced by both parties. If a person is able to empathi e with others, that person will feel that he or she is in a better position to understand others. Can express this kind of empathetic understandding without losing his identity. Have compasssion which includes sensitivity in sensing current events and understanding what is being said during interpersonal communication.

Table 7

Path Coefficients

\begin{tabular}{cccccc}
\hline \hline & $\begin{array}{c}\text { Original } \\
\text { Sample }\end{array}$ & $\begin{array}{c}\text { Sample } \\
\text { Mean }\end{array}$ & STDEV & $\begin{array}{c}\text { T Statistics } \\
\text { (O/STDEV) }\end{array}$ & $\begin{array}{c}\text { P } \\
\text { Values }\end{array}$ \\
\hline $\mathrm{ME} 1 \rightarrow \mathrm{WP}$ & 0,079 & 0,090 & 0,169 & 0,466 & 0,641 \\
$\mathrm{ME} 2 \rightarrow \mathrm{WP}$ & $-0,121$ & $-0,107$ & 0,173 & 0,700 & 0,484 \\
$\mathrm{WE} \rightarrow \mathrm{WP}$ & $-0,058$ & 0,064 & 0,209 & 0,280 & 0,780 \\
$\mathrm{ICS} \rightarrow \mathrm{WP}$ & 0.534 & 0,487 & 0,153 & 3,480 & 0,001 \\
$\mathrm{IT} \rightarrow \mathrm{WP}$ & 0,403 & 0,364 & 0,153 & 2,632 & 0,009 \\
\hline
\end{tabular}

Source: processed data 
In this case, it is necessary to be more descriptive in communication than evaluation, because evaluation attitudes tend to cause defensive reactions in others. Another thing is to be willing to listen and be open to different opinions. Communicating positively in interpersonal communication is based on a positive attitude and respect for others.

Communication is effective in an atmosphere of equality even though no one person is absolutely equal to another in all respects. As for the similarities, there is an element of desire to be able to work together in solving problems, this is manifested in seeing disagreements and disputes between individuals who communicate, more as a desire to understand the differences that exist, rather than seeing it as an opportunity to bring each other down.

While the role of Interpersonal Communication Skills is very much needed to achieve good work performance (Abdurrahman, 2018; Zakaria and Leiwakabessy, 2020; Fanpada, 2020), where if every employee, both lower and upper levels in a department has good Interpersonal Communication Skills. Well, good collaboration will be established, communication and information will run smoothly and this supports the achievement of work performance as expected.

Effective interpersonal communication development to improve employee interpersonal communication skills. Interpersonal communication skills have a relationship with teamwork, wherever effective interpersonal communication will increase cooperation between workers.

Cooperation has a deep relationship with interpersonal communication. There is a relationship between interpersonal communication and teamwork is influenced by comprehensive two-way communication. Cooperation is built on the basis of trust that requires two-way communication, where one of the factors that will affect cooperation is the opportunity to interact with people, that is the technique of fulfilling inter- personal desires. After this desire is fulfilled, there will be an effort from the individual to repay the people who provide the fulfillment of the desire. That kind of thing with good interpersonal communication events can make team members very comfortable, this can however result in conflicts that will occur can be resolved quickly, and workers can feel more comfortable with the surrounding environment to support the success of the work.

This convenience keeps workers moving, so they are more enthusiastic about arriving on time, enthusiastic about completing the tasks they have been assigned. This could be because they feel that they are friendly to each other, have the same feelings, support and equality, then there is no desire to shift responsibility, respect each other, and finally they will devote themselves entirely to the team and to the company.

Basically, information technology systems do not only cover physical things (hardware), but also include things that are not physically visible, namely software, and the most important thing is human resources as users and actors (Kadir and Triwahyuni, 2013).

Data innovation can be in the form of systems and infrastructure strategies (equipment, computer programs, user devices) and strategies for obtaining, transmitting, handling, interpreting, storing, organi ing, and definitively using information. Therefore, information technology provides so much convenience for managing information in the sense of storing, retrieving, and improving data. Information technology can be an innovation that can be utilized or used to develop, handle, obtain, compile, store, control data in various ways to produce quality data (Supianti, 2018).

In addition, employees become end users of several technologies used, such as self-service, benefit options, career planning, or training and development. This is the importance of web access that simplifies the use of the system for employees in fulfilling 
performance. The existence of a technolog based information system refers to the purpose of the knowledge system itself, while in line with information systems support the implementation of providing information for management, as well as support methods for daily operational activities of the company (Silva and Lima, 2017). The most benefit of a technologybased information system is its online and real-time nature. Reports will be generated directly from group action information that reflects the current state of business operations. All recorded transactions will be logged and easy to trace.

In the settings for the use of data innovation, the settings that support users are a form of facilitating conditions that will affect the use of data innovations. Arrangements that support users are carried out by providing readiness and assisting when facing challenges so that some obstacles in their use can be reduced or evacuated.

Work performance resulting from the suitability of the task and technology refers to the efficiency, effectiveness and higher quality of the use of technology that results in better performance in information systems. States that an individual is set to reali e high performance depending on participation, identity, different intelligence, leadership, security, job information, participation, loyalty, resilience and initiative.

Participation between represent-tatives in the organi ation is very necessary, in managing to carry out their obligations and work, both cooperation between superiors and subordinates as well as participation between subordinates. The personality of the employee determines the benefits of future work. Representatives who have a great identity must have an ideal execution. Intelligence will make workers fast and precise in taking care of tasks and work, and insight is obtained from formal education and work experience.

Work experience can be the basis or reference that workers are ready to put themselves in the right conditions, dare to face risks, are ready to face challenges with full responsibility and are ready to communicate well with various parties to maintain productivity, performance and produce competent people in their fields.

Work experience is the level of mastery of knowledge as well as a person's skills that can be measured from the period of work and the breadth of knowledge and abilities. Business skills, especially jobs that require a lot of skill and initiative to react, resulting in a much better product in terms of quantity and quality.

Several factors that influence certain conditions are in line with Handoko (in Basari et al., 2013) as follows: 1) Personal background, as well as education, courses, training, employment. To show what someone has written off in the past. 2) Talents and interests, to estimate a person's interests and abilities or talents. 3) Attitude and desire to predict individual responsibility and authority. 4) Analytical and artistic skills to know assessment and analysis skills. Technical skills and skills, to assess strength in the technical aspects of the job.

Work experience is indeed important and needed because it can affect work performance (Pratiwi et al., 2019), but what happens in aircraft maintenance and repair workshops that have implemented good regional management/organi ation, complete data information, current work procedures, supporting work equipment for To support the completeness of the activities, it can be understood that the role of work experience and its influence on work performance is not significant.

\section{CONCLUSION AND SUGGESTION}

\section{Conclusion}

The result of this study as follow:

1. Work experience does not have a significant effect on work performance, because repairing aircraft requires other things apart from the experience itself for repairs. 
2. Interpersonal Communication Skills have a significant effect on Work Perfor-mance, because interpersonal communi-cation is needed in carrying out aircraft repairs, so that mistakes do not occur that will damage the repair itself.

3. The use of Information Technology has a significant effect on Work Performance, which shows the importance of information technology for aircraft repair as an important measure in determining work performance

4. The use of Information Technology is only as a predictor that causes between Job Performance and Interpersonal Communication Skills on job performance.

\section{Suggestion}

Because the most significant influence on work performance is interpersonal communication skills, the suggestion is to strengthen the daily accountability process, as follows:

1. A series of short review sessions (loop meetings), which provides facilitation in overcoming problems.

2. Take action to close gaps, companies should not be trapped in euphoria or old habits and must immediately carry out digital transformation. This is in line with industry 4.0, this is important because it provides an opportunity to accelerate the achievement of the company's vision and mission

3. Accountability visualiation: is the obligetion of an agency to account for the success or failure of the implementation of programs and activities, to achieve the organi ation's mission in a measurable manner with the targets/performance targets that have been set and then set forth in a performance report compiled periodically

\section{REFFERENCE}

Abdurrahman, N. H. 2018. The Effect of Interpersonal Communication Skills and Work Motivation on Performance of Marketing Employee. International
Journal of Engineering $\mathcal{E}$ Technology 7(2.29): 190-195.

Al Eqab, M. and D. Adel. 2013. The Impact of IT Sophistications on the Perceived Usefulness of Accounting Information Characteristics among Jordanian Listed Companies. International Journal of Business and Social Science 4(3): 145-155.

Arikunto, S. 2012. Prosedur Penelitian Suatu Pendekatan Praktek. Rineka Cipta. Jakarta.

Astika, I. P. A. E. P. and I. W. P. Wirasedana. 2020. The Effect of Information Technology, the Participation Management, the Ability of Accounting Information Systems Users, Education and Training in Performance Management. American Journal of Humanities and Social Sciences Research (AJHSSR) 4(3): 177-183.

Basari, A. S. H., B. Hussin, I. G. P. Ananta, and J. Zeniarja. 2013. Opinion Mining of Movie Review using Hybrid Method of Support Vector Machine and Particle Swarm Optimization. Procedia Engineering 53: 453-462.

Cragg, P., A. Mills, and T. Suraweera. 2010. Understanding IT Management in SMEs. Electronic Journal of Information Systems Evaluation 13(1): 27-34.

Daryanto and Rahardjo. 2016. Teori Komunikasi. Gava Media. Yogyakarta.

Daulay, I. N., S. S. Nurutami, and D. D. Daniel. 2013. Analisis Maintenance Reliability terhadap Mean Time between Failures (MTBF) Facilities pada Industri Pulp \& Paper. Jurnal Ekonomi 21(4): 1-18.

Fanpada, N. 2020. The Influence of Leadership and Interpersonal Communication on the Performance of Lecturers of Tribuana University Kalabahi, AlorNTT District. International Journal of Education, Information Technology, and Others 3(2): 372-380.

Granell, C., S. Gómez, and A. Arenas. 2014. Competing Spreading Processes on Multiplex Networks: Awareness and Epidemics. Physical Review E 90(1): 012808-012815. 
Hasibuan, M. S. P. 2016. Manajemen Sumber Daya Manusia. Edisi Revisi. Penerbit PT Bumi Aksara. Jakarta.

Heizer, J. and B. Render. 2011. Manajemen Operasi. Buku 2 Edisi 9. Salemba Empat. Jakarta.

Kadir, A., and T. C. Triwahyuni. 2013. Pengantar Teknologi Informasi. Edisi Revisi. Andi Offset. Yogyakarta.

Laksana, M. W. 2015. Psikologi Komunikasi; Membangun Komunikasi yang Efektif Dalam Interaksi Manusia. Pustaka Setia. Bandung.

Lindawati and I. Salamah. 2012. Pemanfaatan Sistem Informasi dan Teknologi Informasi dan Pengaruhnya terhadap Kinerja Individual Karyawan. Jurnal Akuntansi dan Keuangan 14(1): 56-68.

Muntazeri, S. and A. Indrayanto. 2018. The Impact of Education, Training and Work Experience on Job Satisfaction and Job Performance. Jurnal Akuntansi, Manajemen dan Ekonomi 20(2): 50-69.

Nasir, M., B. Jafar, and Z. M. Mohammad. 2020. Pengaruh Gaya kepemimpinan situasional, Budaya Organisasi, dan Komitmen Organisasi terhadap Kinerja Pegawai. Celebes Equilibrum Journal 1(2): 1-11.

Noor, J. 2011. Metodologi Penelitian: Skripsi, Tesis, Disertasi, dan Ilmiah. Kencana. Jakarta.

Okoro, E., M. C. Washington, and O. Thomas. 2017. The Impact of Interpersonal Communication Skills on Organizational Effectiveness and Social SelfEfficacy: a Synthesis. International Journal of Language and Linguistics 4(3): 28-32.

Pratiwi, N. M. P. P., I. M. Sukartha, I. G. A. M. A. D. Putri, and I. G. N. A. Suaryana. 2019. Effects of Intelligence, Knowledge, Work Experience and Additional Employee Income on Performance of State Civil Apparatus. International Journal of Contemporary Research and Review 10(01): 21245-21254.

Rosman. 2014. Analisis Kinerja Pegawai dalam Penyelenggaraan Pemerintah di
Kecamatan Sambaliung Kabupaten Berau. E-Journal Ilmu Pemerintahan 2(2): 2753-2766.

Rusman, D. K. and C. Riyana. 2012 Pembelajaran Berbasis Teknologi Informasi dan Komunikasi: Mengembangkan Profesionalisme Guru. PT. Raja Grafindo Persada. Jakarta.

Silva, M. S. A. and C. G. D. S. Lima. 2017. The Role of Information Systems in Human Resource Management. Intechopen Chapter 7: 113-126.

Supianti, I. I. 2018. Pemanfataan Teknologi Informasi dan Komunikasi (TIK) dalam Pembelajaran Matematika. MENDIDIK: Jurnal Kajian Pendidikan dan Pengajaran 4(1): 63-70.

Sutrisno, E. 2011. Manajemen Sumber Daya Manusia. Edisi Kedua. Kencana Prenada Media Group. Jakarta.

Sugiyono. 2017. Metode Penelitian Kuantitatif, Kualitatif, dan RED. Alfabeta. Bandung.

Sevrani, K. 2011. Information Systems and Information Technology as Strategic Tools-Their use in Albanian Business. Journal of Knowledge Management, Economics and Information Technology 1(6): 122.

Susanti, N. I. and A. Wariati. 2015. Kebijakan Program Sosial Bank Indonesia (PSBI) Kantor Perwakilan Surakarta dalam Rangka Meningkatkan Kesejahteraan Rakyat. Proceeding Seminar Nasional dan Call for Papers Peran Kepemimpinan Nasional dalam Mewujudkan Kedaulatan Energi Menuju Kedaulatan Ekonomi Indonesia: 111-124.

Usman, A., A. Kusumawati, dan A. Mannan. 2021. The Effect of Work Experience, Motivation, and Culture on Auditor Performance Mediated by Self Efficacy. Psychology and Education Journal 58(1): 474-489.

Valkenburg, P. M. and J. Peter. 2011. Online Communication among Adolescents: An Integrated Model of It's Attraction, Opportunities, and Risk. Journal of Adolescent Health 48(2): 121-127. 
Wariati, N., Dahniar, and T. Sugiati. 2015. Pengaruh Disiplin Kerja dan Pengalaman Kerja terhadap Kinerja Pegawai Dinas Pendapatan Pengelolaan Keuangan dan Aset Kabupaten Barito Timur. Jurnal Wawasan Manajemen 3(3): 217-228

Wulandari, N. 2017. Influence of Education and Work Experience on Work Motivation and Job Performance at Branch Office of Bank, J Trust Bank
Surabaya. The Spirit of Society Journal 1(1): $1-20$.

Zakaria, I. H. and T. F. F. Leiwakabessy. 2020. Pengaruh Penggunaan Teknologi Informasi, Kemampuan Berkomunikasi Interpersonal, dan Gaya kepemimpinan terhadap Kinerja Karyawan (Studi Empiris pada Bank Syariah di Kota Ambon). JurnalAkutansi: Transparansi dan Akuntabilitas 8(2): 117-126. 